Supporting Information

\title{
An Easily Available Ratiometric Reaction-based AIE Probe for Carbon Monoxide Light-up Imaging
}

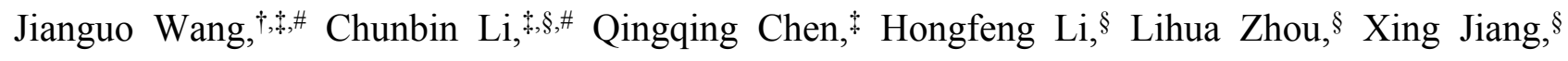
Mengxue Shi, ${ }^{\ddagger}$ Pengfei Zhang, ${ }^{\S, *}$ Guoyu Jiang ${ }^{\dagger, \downarrow}, *$ and Ben Zhong Tang ${ }^{\perp, *}$

$\uparrow$ College of Chemistry and Chemical Engineering, Inner Mongolia Key Laboratory of Fine Organic Synthesis, Inner Mongolia University, Hohhot 010021, China. * E-mail: jiangguoyu@mail.ipc.ac.cn

†Key Laboratory of Organo-Pharmaceutical Chemistry, Gannan Normal University, Ganzhou 341000, China.

§Guangdong Key Laboratory of Nanomedicine, CAS Key Laboratory of Health Informatics, Shenzhen Bioactive Materials Engineering Lab for Medicine, Institute of Biomedicine and Biotechnology, Shenzhen Institutes of Advanced Technology, Chinese Academy of Sciences, Shenzhen 518055, China. * E-mail: pf.zhang@siat.ac.cn $\perp$ Department of Chemistry, Hong Kong Branch of Chinese National Engineering Research Center for Tissue Restoration and Reconstruction, Institute for Advanced Study, Division of Biomedical Engineering, Division of Life Science, State Key Laboratory of Molecular Neuroscience and Institute of Molecular Functional Materials, The Hong Kong University of Science and Technology (HKUST), Clear Water Bay, Kowloon, China. HKUST Shenzhen Research Institute, No. 9 Yuexing 1st RD, South Area Hi-tech Park, Nanshan, Shenzhen 518057, China.

* E-mail: tangbenz@ust.hk

\#These authors contributed equally to this work. 


\section{Table of Contents}

\section{Experiment section:}

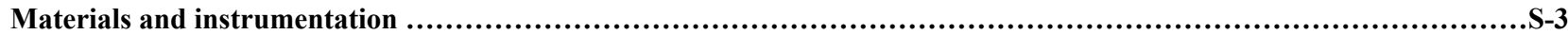

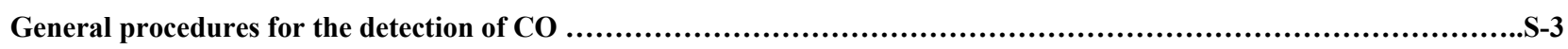

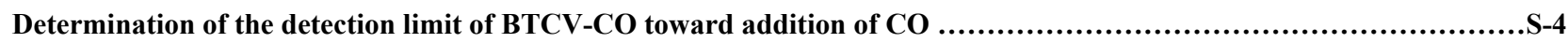

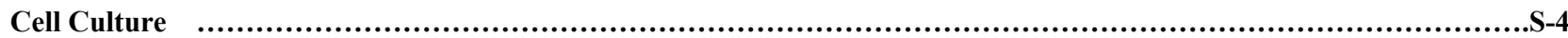

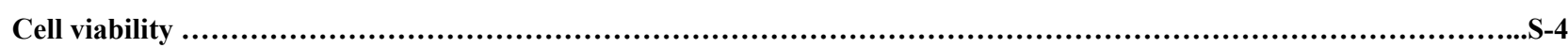

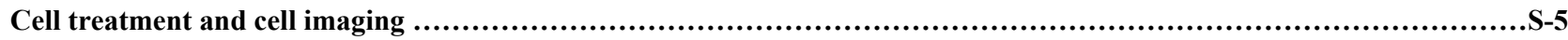

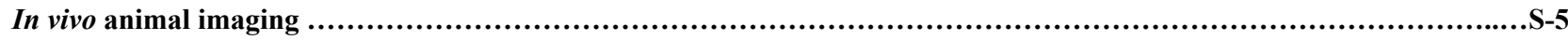

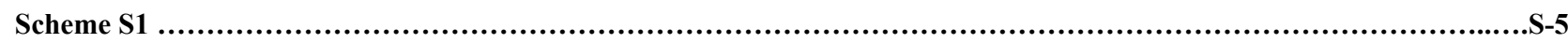

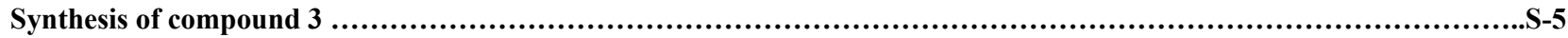

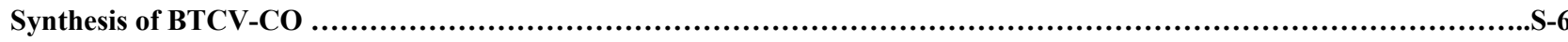

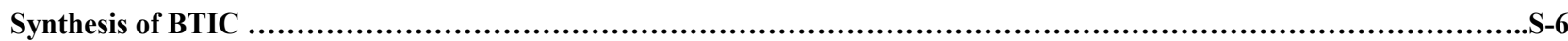

\section{Figures and tables:}

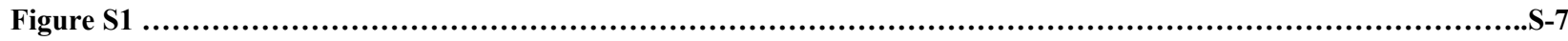

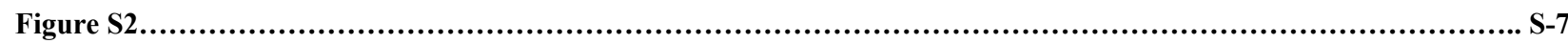

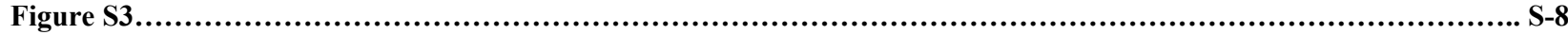

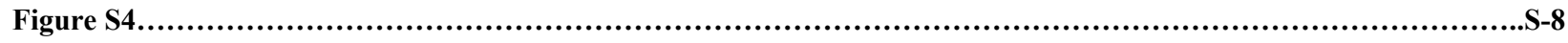

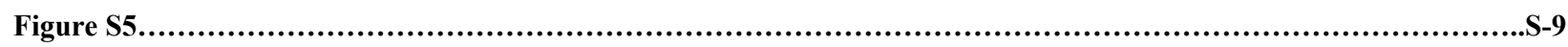

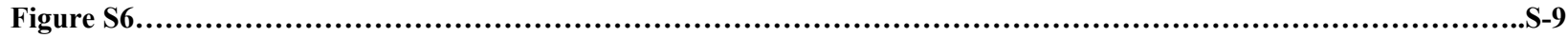

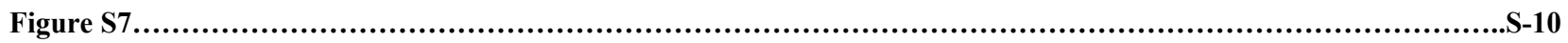

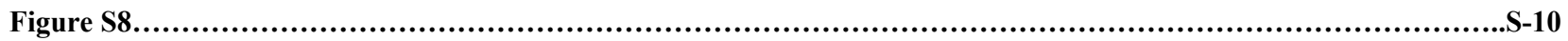

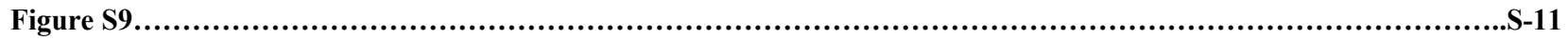

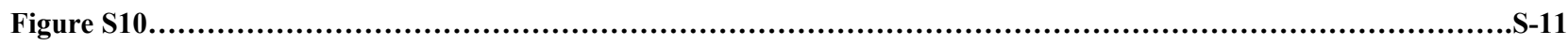

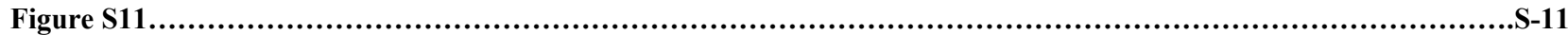

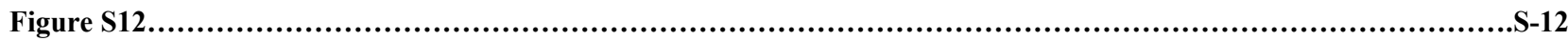

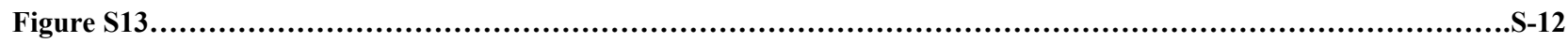

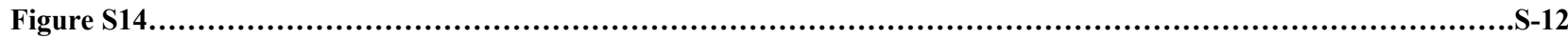

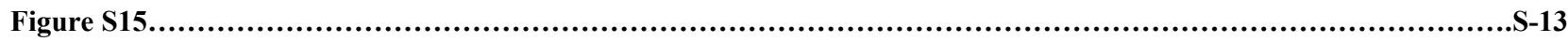

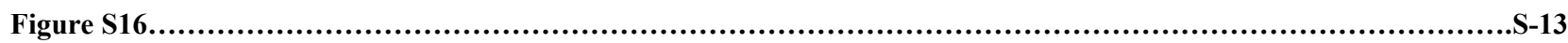

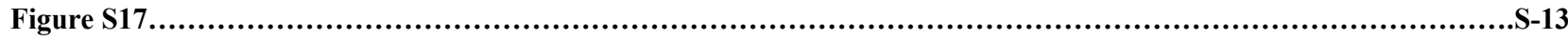

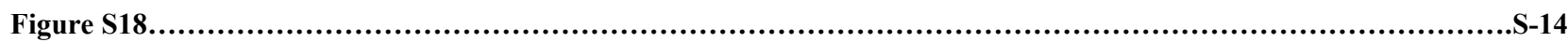

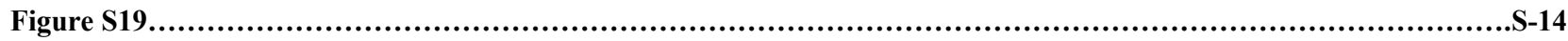

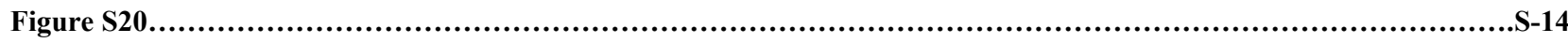

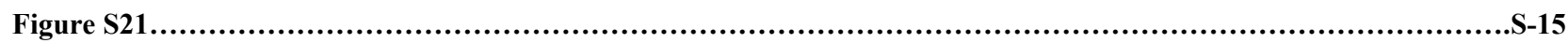

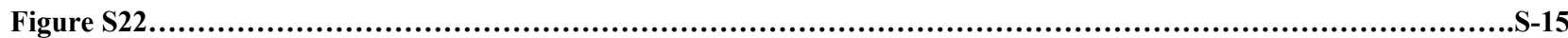

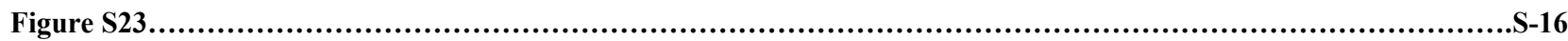

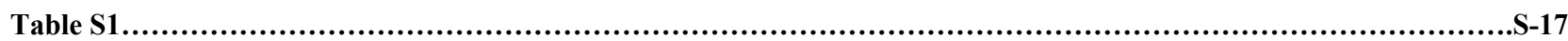

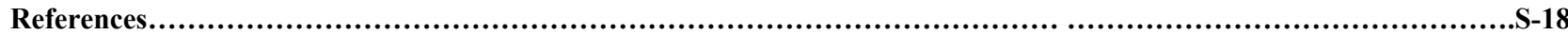




\section{Experiment section:}

\section{Materials and instrumentation}

Chemicals were purchased from Energy-Chemical, Sigma-Aldrich, J\&K and used without further purification. Solvents and other common reagents were obtained from Sigma-Aldrich. ${ }^{1} \mathrm{H}$ NMR and ${ }^{13} \mathrm{C}$ NMR spectra were measured on a Bruker ARX $400 \mathrm{MHz}$ spectrometer. High-resolution mass spectra (HRMS) were recorded on a GCT Premier CAB 048 mass spectrometer operating in MALDI-TOF mode. UV-vis absorption spectra were recorded on a Rarian 50 Conc UV-Visible spectrophotometer. Fluorescence emission spectra were recorded on a Edinburgh FS5 fluorescence spectrophotometer. Absolute fluorescence quantum yield were measured on Hamamatsu C11347-11 Quantaurus-QY Absolute PL quantum yield spectrometer. Cellular imaging experiments were performed with confocal laser scanning microscope (TCS SP5, Leica, Germany) equipped with Argon, red $\mathrm{HeNe}$, and green HeNe lasers.

\section{General procedures for the detection of $\mathrm{CO}$}

Unless otherwise noted, all the spectral measurements were performed in $5 \mathrm{mM}$ phosphate buffer ( $\mathrm{pH} 7.4$, containing 5\% DMSO) according to the following procedure. The stock solution (1.0 mM) of probe BTCV-CO was first prepared in DMSO. $10 \mu \mathrm{L}$ of BTCV-CO stock solution was added to $2 \mathrm{~mL}$ PBS followed by addition of different volume of CO solution. The mixture was incubated for certain times at $37{ }^{\circ} \mathrm{C}$ and then, the reaction solution was transferred to a quartz cell with $1 \mathrm{~cm}$ optical length for measurements. In the meantime, the blank solution without CO was also prepared and measured under the same conditions for comparison.

$\mathrm{CO}$ was prepared from $\left[\mathrm{Ru}(\mathrm{CO})_{3} \mathrm{Cl}_{2}\right]_{2}(\mathrm{CORM}-2)$ in aqueous solution. Hydrogen peroxide $\left(\mathrm{H}_{2} \mathrm{O}_{2}\right)$ and hypochlorite $\left(\mathrm{ClO}^{-}\right)$were delivered from $30 \%$ and 5\% aqueous solutions, respectively. Hydroxyl radical $(\cdot \mathrm{OH})$ was generated by reaction of $100 \mu \mathrm{M} \mathrm{Fe}^{2+}$ with $100 \mu \mathrm{M} \mathrm{H}_{2} \mathrm{O}_{2}$. $\mathrm{ROO} \cdot$ was generated from 2,2'-azobis(2-amidinopropane)dihydrochloride (AAPH), which was dissolved in deionizer water and then stirred at $25^{\circ} \mathrm{C}$ for $30 \mathrm{~min}$. Theoretically, 1 equiv of AAPH will generate 2 equiv of ROO•. R stands for 2-amidinoisopropyl. ONOO- was prepared according to the literature and modified. ${ }^{\mathrm{S} 1} \mathrm{~A}$ mixture of $50 \mathrm{mM}$ sodium nitrite and $50 \mathrm{mM}$ hydrogen peroxide in $50 \mathrm{~mL}$ of ice-cold water was rapidly stirred in a $250 \mathrm{~mL}$ beaker. A solution of hydrochloric acid (1 M, $25 \mathrm{~mL})$ is rapidly thrown into the nitrite/peroxide solution followed by a solution of sodium hydroxide (1.5 
M, $25 \mathrm{~mL}$ ) approximately 1 second later. The concentration of $\mathrm{ONOO}^{-}$was determined by UV spectrophotometry $\left(\varepsilon_{302}=1670 \mathrm{~L} \cdot \mathrm{mol}^{-1} \cdot \mathrm{cm}^{-1}\right)$. Angeli's salt $($ AS $)$ was purchased from Santa Cruz Biotechnology, and HNO was prepared from AS using double-distilled water.

\section{Determination of $\mathrm{CO}$ concentration released from CORM-2}

The release of CO from CORM-2 was assessed spectrophotometrically by measuring the conversion of deoxymyoglobin (deoxy-Mb) to carbonmonoxy myoglobin (MbCO). The amount of $\mathrm{MbCO}$ formed was quantified by measuring the absorbance at $540 \mathrm{~nm}$ (extinction coefficient=15.4 $\left.\mathrm{mmol} \cdot \mathrm{L}^{-1} \cdot \mathrm{cm}^{-1}\right)$. Myoglobin solutions (66 $\mu \mathrm{mol} / \mathrm{L}$ final concentration) were prepared fresh by dissolving the protein in $0.04 \mathrm{~mol} / \mathrm{L}$ phosphate buffer $(\mathrm{pH}=6.8)$. Sodium dithionite $(0.1 \%)$ was added to convert myoglobin to deoxy-Mb. CO released from CORM-2 was quantified by adding aliquots of stock solutions $(10 \mu \mathrm{L})$ of CORM-2 in DMSO directly to the myoglobin solution.

\section{Determination of the detection limit of BTCV-CO toward addition of CO}

Based on the linear fitting in Figure $2 \mathrm{C}$ and Figure S14, the detection limit $(C)$ is estimated as follows:

$$
C=3 \sigma / B
$$

Where $\sigma$ is the standard deviation obtained from three individual fluorescent intensity ratio $\left(I_{546} / I_{710}\right)$ or $\left(\left(I-I_{0}\right) / I_{0}\right)$ at $546 \mathrm{~nm}$ of BTCV-CO $(5 \mu \mathrm{M})$ without any CO and $B$ is the slope obtained after linear fitting the titration curves within certain ranges.

\section{Cell cultures}

The MCF-7 cells were cultured in DMEM (containing 10\% heat-inactivated FBS, $100 \mathrm{mg} \cdot \mathrm{mL}^{-1}$ penicillin and $100 \mathrm{mg} \cdot \mathrm{mL}^{-1}$ streptomycin) at $37{ }^{\circ} \mathrm{C}$ in a humidified incubator with $5 \% \mathrm{CO}_{2}$. Before the experiments, the cells were pre-cultured until confluence was reached.

\section{Cell viability}

Cell viability was determined by using MTT assay which is based on the reduction of 3-(4,5-dimethythiazol-2-yl)-2,5-diphenyl tetrazolium bromide (MTT, yellow in color) into formazan (blue color) by mitochondrial succinate dehydrogenase. Dispense $100 \mu \mathrm{L}$ of cell suspension (5000 cells/well) in a 96-well plate. Pre-incubate the plate for $24 \mathrm{~h}$ at $37{ }^{\circ} \mathrm{C}$ in a humidified incubator with $5 \% \mathrm{CO}_{2}$. Add $10 \mu \mathrm{L}$ of various concentrations of BTCV-CO into the culture media in the plate. After incubating the plate for $24 \mathrm{~h}$ in the incubator, the cell medium were 
exchanged with fresh medium $(100 \mu \mathrm{L})$, and then $20 \mu \mathrm{L}$ of the MTT $(5 \mathrm{mg} / \mathrm{mL})$ solution was then added. Medium was removed after the incubation period of 4 hours followed by the addition of 100 $\mu \mathrm{L}$ of DMSO to dissolve the formazan crystals. Absorbance was taken at $600 \mathrm{~nm}$ by an ELISA Plate Reader (Biotek Synergy HT). Untreated cells were taken as control. All the experiments were performed in triplicate. Cell viability was determined by using given formula:

$$
\text { Cell viability }(\%)=\frac{\text { Absorbance of treated cells }}{\text { Absorbance of untreated cells }}
$$

\section{Cell treatment and cell imaging}

For the imaging of CO, the MCF-7 cells were incubated with $5 \mu \mathrm{M} \mathrm{BTCV-CO}$ and $5 \mu \mathrm{M} \mathrm{PdCl}_{2}$ for $30 \mathrm{~min}$ at $37{ }^{\circ} \mathrm{C}$, then the media was replaced with PBS buffer and the cells were treated with different concentrations of CORM-2 $(0,10,20$ and $50 \mu \mathrm{M})$ for $30 \mathrm{~min}$. The imaging was acquired using a confocal laser scanning microscope (TCS SP5, Leica, Germany). For cell imaging, the cells were washed with PBS three times. A $476 \mathrm{~nm}$ laser was used as the light source and emission was collected from 500 to $580 \mathrm{~nm}$ (green channel) and 580 to $700 \mathrm{~nm}$ (red channel).

\section{In vivo animal imaging}

Female BALB/c white mice (4-6 weeks old and weighted 25-30 g) were purchased from Vital River Laboratory Animal Technology Co. Ltd (Beijing, China) and all animals received care incompliance with the guidelines outlined in the Guide for the Care and Use of Laboratory Animals. The procedures were approved by Shenzhen Institutes of Advanced Technology, Chinese Academy of Sciences Animal Care and Use Committee. The probe solution ( $25 \mu \mathrm{L}, 1 \mathrm{mM}$ in DMSO) was injected to white mice via intraperitoneal injection, followed by an injection of CORM-2 (75 $\mu \mathrm{L}, 2$ $\mathrm{mM})$. Control group was injected with $75 \mu \mathrm{L}$ of PBS. Images were taken after injection using the Maestro in vivo imaging system.

Scheme S1. Synthetic route to BTIC.
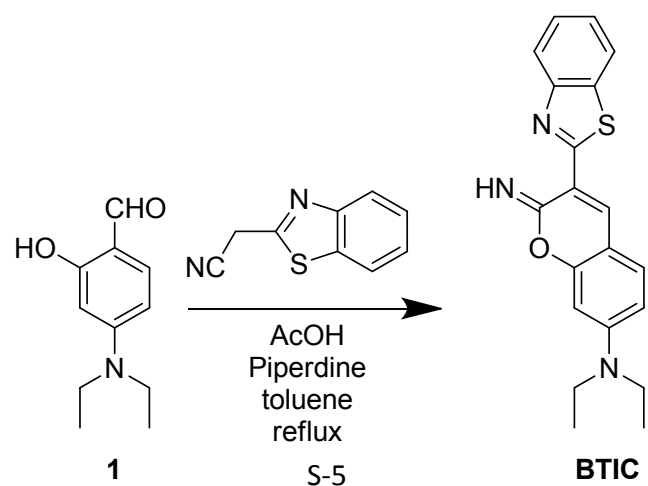
Synthesis of compound 3. 4-(Diethylamino)salicylaldehyde (compound 1, $193.0 \mathrm{mg}, 1.0 \mathrm{mmol}$ ), allyl bromide (compound 2, $242.0 \mathrm{mg}, 2.0 \mathrm{mmol}$ ) and $\mathrm{K}_{2} \mathrm{CO}_{3}(415.0 \mathrm{mg}, 3.0 \mathrm{mmol})$ was mixed in $10 \mathrm{~mL} \mathrm{CH}_{3} \mathrm{CN}$. The mixture was refluxed under the nitrogen atmosphere. The reaction was monitored by TLC. When compound 1 disappeared, the mixture was cooled to room temperature and filtrated to remove any solids. The obtained solution was washed with brine and extracted with dichloromethane. The organic layer was dried over anhydrous $\mathrm{Na}_{2} \mathrm{SO}_{4}$. After concentrated, the residue was purified by silica gel chromatography with petroleum ether/dichloromethane $(1: 2 \sim 2: 1$, $v / v)$ to give compound 3 as a white solid $(212.0 \mathrm{mg}, 91 \%) .{ }^{1} \mathrm{H} \mathrm{NMR}\left(400 \mathrm{MHz}, \mathrm{CDCl}_{3}\right) \delta 10.09(\mathrm{~s}$, 1H), 7.59 (d, $J=8.9 \mathrm{~Hz}, 1 \mathrm{H}), 6.16(\mathrm{~d}, J=10.4 \mathrm{~Hz}, 1 \mathrm{H}), 5.94(\mathrm{~d}, J=2.0 \mathrm{~Hz}, 2 \mathrm{H}), 5.35(\mathrm{~d}, J=18.3$ $\mathrm{Hz}, 1 \mathrm{H}), 5.21$ (d, $J=10.6 \mathrm{~Hz}, 1 \mathrm{H}), 4.52$ (d, $J=5.0 \mathrm{~Hz}, 2 \mathrm{H}), 3.32-3.27(\mathrm{~m}, 4 \mathrm{H}), 1.17-1.08$ (m, 6H). ${ }^{13} \mathrm{C}$ NMR $\left(100 \mathrm{MHz}, \mathrm{CDCl}_{3}\right) \delta 186.77,163.21,153.79,132.97,130.18,117.35,114.18,104.41$, $93.67,68.78,44.74,12.52$.

Synthesis of BTCV-CO. A mixture of compound 3 (117.1 $\mathrm{mg}, 0.5 \mathrm{mmol})$, benzothiazole-2-yl-acetonitrile $(174.2 \mathrm{mg}, 1.0 \mathrm{mmol})$, piperidine $(150 \mu \mathrm{L}, 1.6 \mathrm{mmol})$, acetic acid $(150 \mu \mathrm{L}, 2.6 \mathrm{mmol})$ in $25 \mathrm{~mL}$ toluene was refluxed under nitrogen atmosphere for $16 \mathrm{~h}$. After cooling to room temperature, the mixture was washed with brine and extracted with dichloromethane. The organic layer was dried over anhydrous $\mathrm{Na}_{2} \mathrm{SO}_{4}$. After concentrated, ethyl ether/dichloromethane $(15: 1, v / v)$ was added and BTCV-CO was precipitated and collected as a red solid (166.1 mg, 85\%). ${ }^{1} \mathrm{H}$ NMR (400 MHz, $\left.\mathrm{CDCl}_{3}\right) \delta 8.57(\mathrm{~s}, 1 \mathrm{H}), 8.43$ (d, J = 9.2 Hz, 1H), 8.01 $(\mathrm{d}, J=8.1 \mathrm{~Hz}, 1 \mathrm{H}), 7.83(\mathrm{~d}, J=7.9 \mathrm{~Hz}, 1 \mathrm{H}), 7.49-7.41(\mathrm{~m}, 1 \mathrm{H}), 7.38-7.30(\mathrm{~m}, 1 \mathrm{H}), 6.37(\mathrm{~m}$, $1 \mathrm{H}), 6.20-6.03(\mathrm{~m}, 2 \mathrm{H}), 5.50(\mathrm{~d}, J=18.8 \mathrm{~Hz}, 1 \mathrm{H}), 5.37$ (d, $J=11.9 \mathrm{~Hz}, 1 \mathrm{H}), 4.67-4.65(\mathrm{~m}, 2 \mathrm{H})$, 3.45-3.40 (m, 4H), 1.24-1.21 (m, 6H). $\left.{ }^{13} \mathrm{C} \mathrm{NMR} \mathrm{(100} \mathrm{MHz,} \mathrm{CDCl}_{3}\right) \delta 165.91,160.46,153.99$, $152.58,141.21,134.42,133.01,130.53,126.32,124.85,122.90,121.26,118.63,117.65,110.04$, 105.25, 96.42, 94.36, 69.28, 44.90, 12.72. HRMS (MALDI-TOF): $m / z:[\mathrm{M}]^{+}$calcd for $\mathrm{C}_{23} \mathrm{H}_{23} \mathrm{~N}_{3} \mathrm{OS}^{+}$: 389.1562; found: 389.1602 .

Synthesis of BTIC. A mixture of compound 1 (97.1 mg, $0.5 \mathrm{mmol})$, benzothiazole-2-yl-acetonitrile (174.3 mg, $1.0 \mathrm{mmol})$ piperidine $(150 \mu \mathrm{L}, 1.6 \mathrm{mmol})$, acetic acid $(150 \mu \mathrm{L}, 2.6 \mathrm{mmol})$ in $25 \mathrm{~mL}$ toluene was refluxed under nitrogen atmosphere for $16 \mathrm{~h}$. After cooling to room temperature, the mixture was washed with brine and extracted with dichloromethane. The organic layer was dried over anhydrous $\mathrm{Na}_{2} \mathrm{SO}_{4}$. After concentrated, ethyl ether/dichloromethane (30:1, v/v) was added and BTIC was precipitated and collected as a red solid (161.2 mg, 92\%). ${ }^{1} \mathrm{H}$ NMR $\left(400 \mathrm{MHz}, \mathrm{CDCl}_{3}\right) \delta$ 
$8.87(\mathrm{~s}, 1 \mathrm{H}), 8.00(\mathrm{~d}, J=8.1 \mathrm{~Hz}, 1 \mathrm{H}), 7.92(\mathrm{~d}, J=7.6 \mathrm{~Hz}, 1 \mathrm{H}), 7.50-7.42(\mathrm{~m}, 2 \mathrm{H}), 7.37-7.31(\mathrm{~m}$, $1 \mathrm{H}), 6.63(\mathrm{~d}, J=11.4 \mathrm{~Hz}, 1 \mathrm{H}), 6.52(\mathrm{~d}, J=2.3 \mathrm{~Hz}, 1 \mathrm{H}), 3.45-3.40(\mathrm{~m}, 4 \mathrm{H}), 2.60(\mathrm{~s}, 1 \mathrm{H}), 1.24-1.21$ (m, 6H). ${ }^{13} \mathrm{C}$ NMR (100 MHz, $\left.\mathrm{CDCl}_{3}\right), \delta 161.80,161.06,157.03,152.57,152.10,142.03,136.26$, $130.77,126.06,124.42,122.12,121.56,112.40,109.98,108.67,96.97,45.07,40.96,12.48$. HRMS (MALDI-TOF): $m / z$ : $[\mathrm{M}+\mathrm{H}]^{+}$calcd for $\mathrm{C}_{20} \mathrm{H}_{20} \mathrm{~N}_{3} \mathrm{OS}^{+}: 350.1327$; found: 350.1321 .

\section{Figures and tables:}
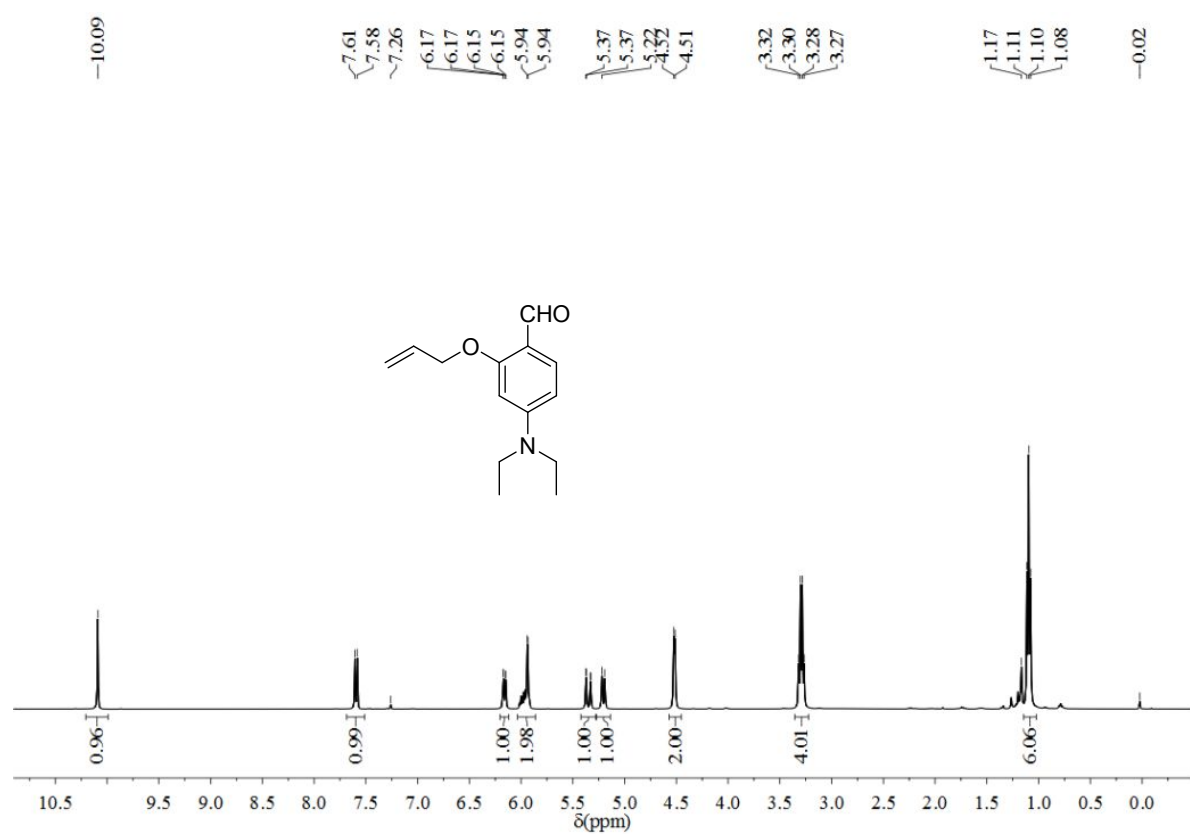

Figure S1. ${ }^{1} \mathrm{H}$ NMR spectrum of compound 3 in $\mathrm{CDCl}_{3}$.
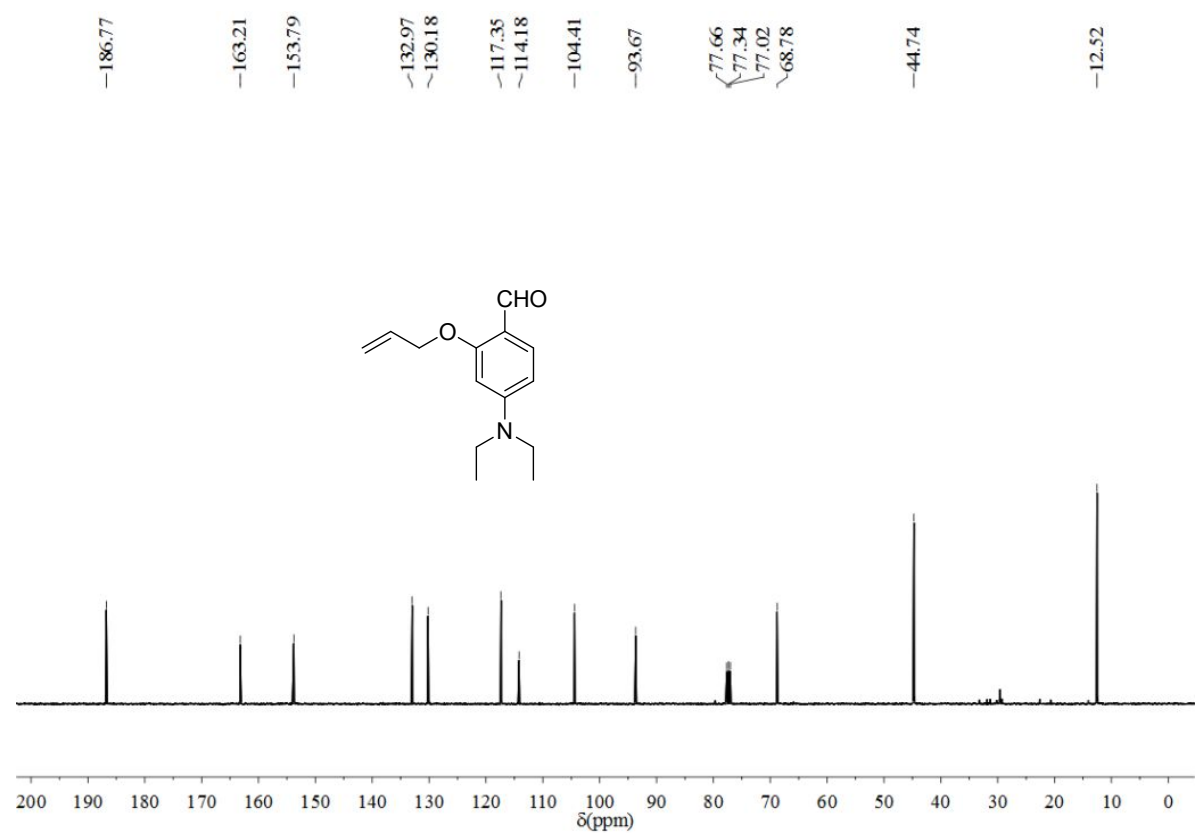

Figure S2. ${ }^{13} \mathrm{C}$ NMR spectrum of compound 3 in $\mathrm{CDCl}_{3}$. 


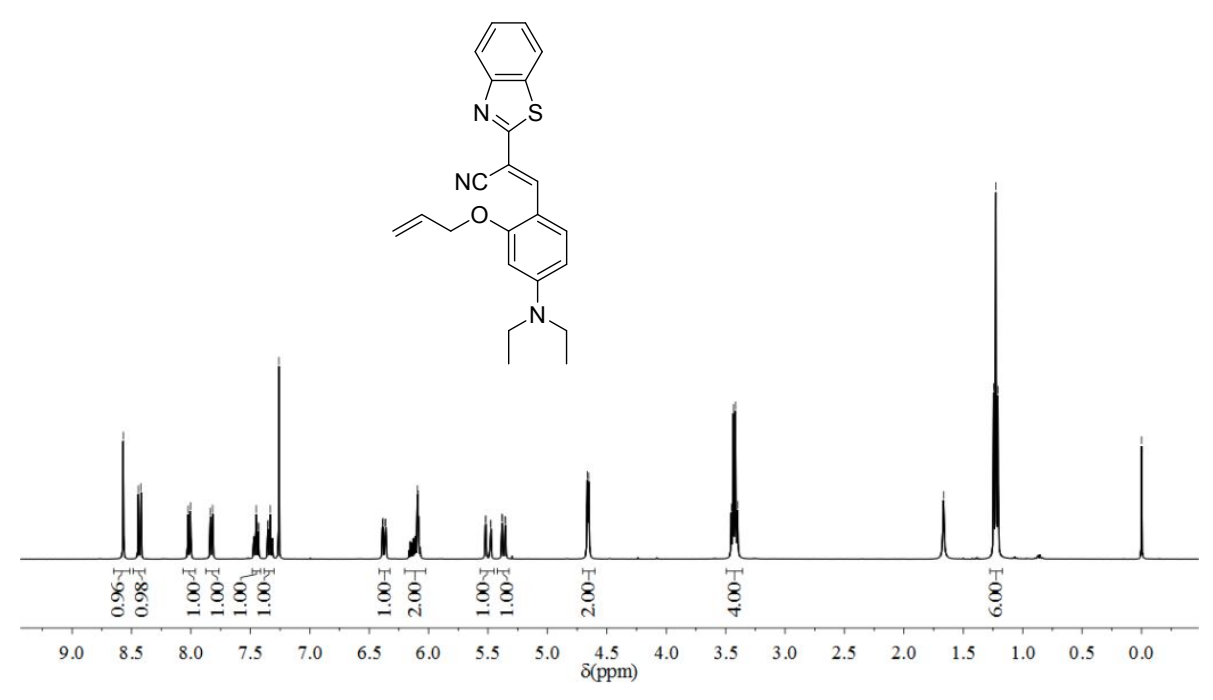

Figure S3. ${ }^{1} \mathrm{H}$ NMR spectrum of BTCV-CO in $\mathrm{CDCl}_{3}$.
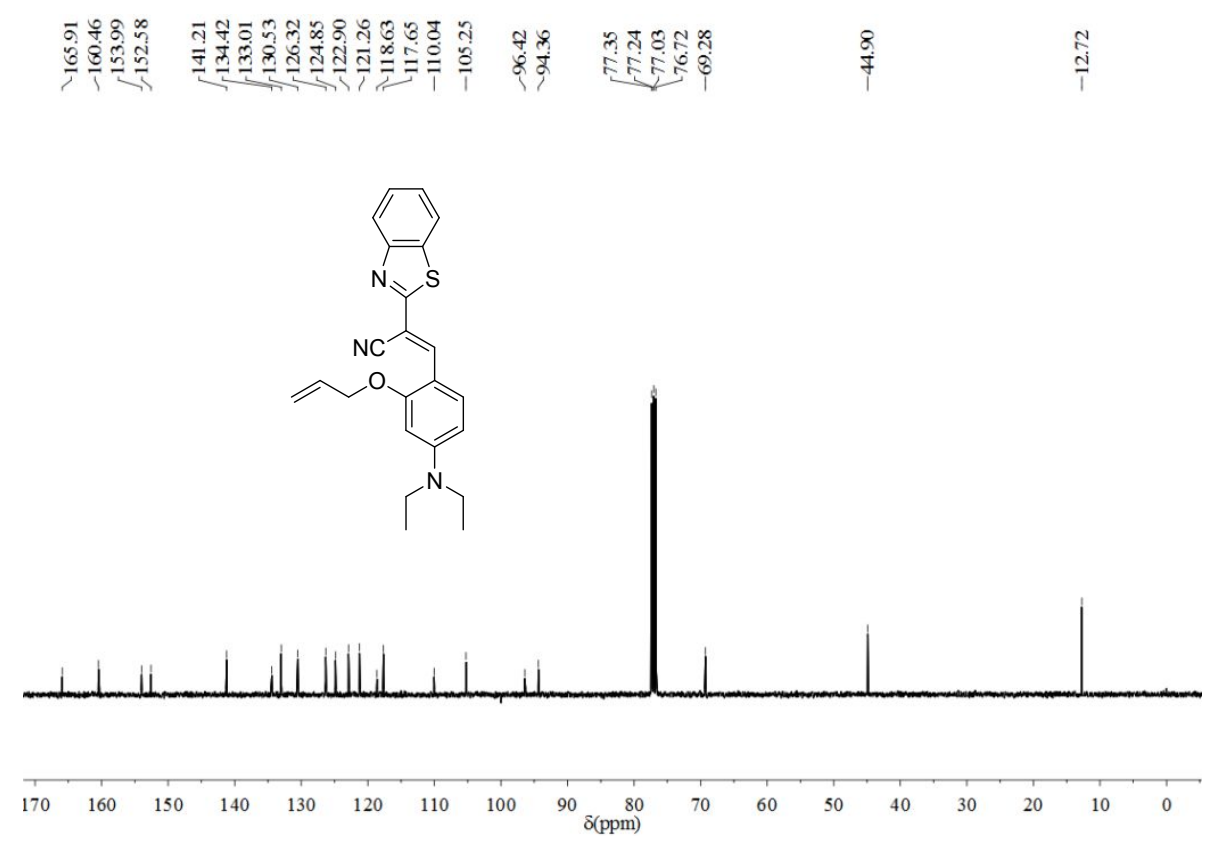

Figure S4. ${ }^{13} \mathrm{C}$ NMR spectrum of BTCV-CO in $\mathrm{CDCl}_{3}$. 


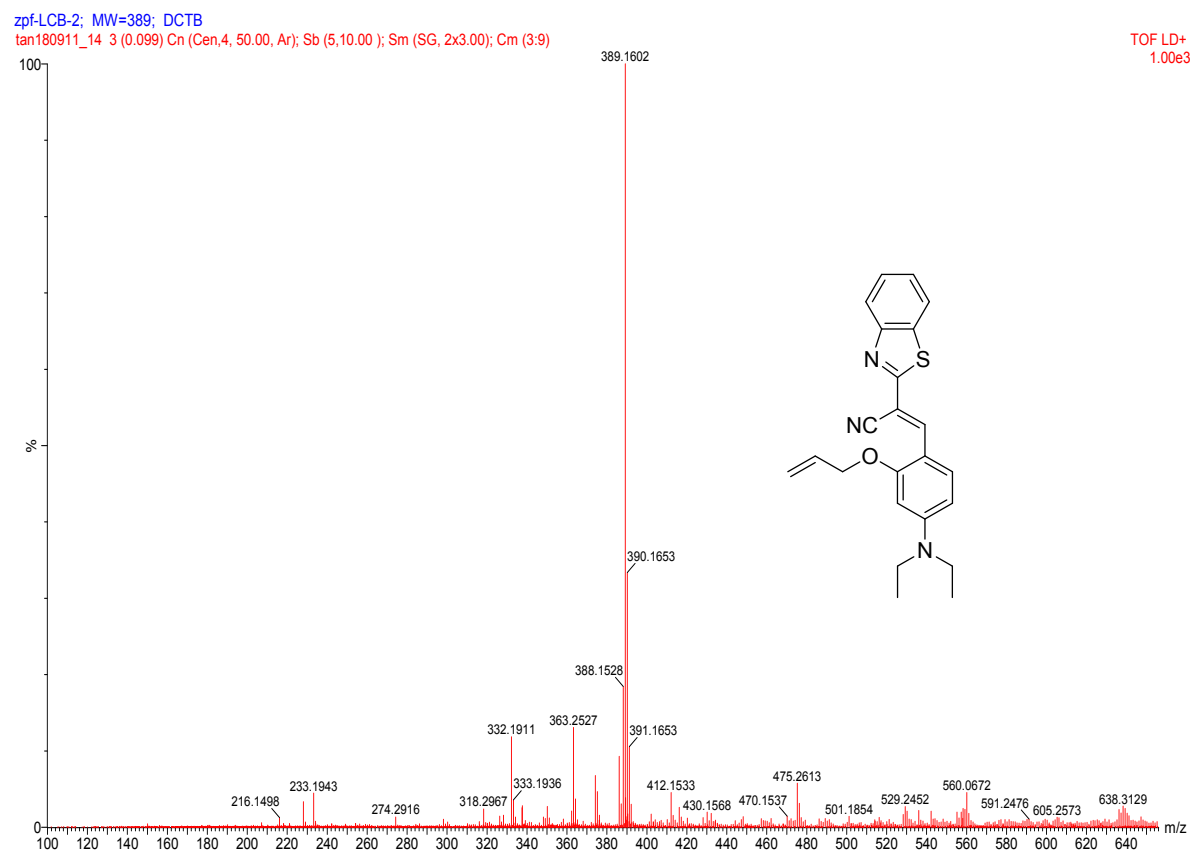

Figure S5. HRMS spectrum of BTCV-CO.

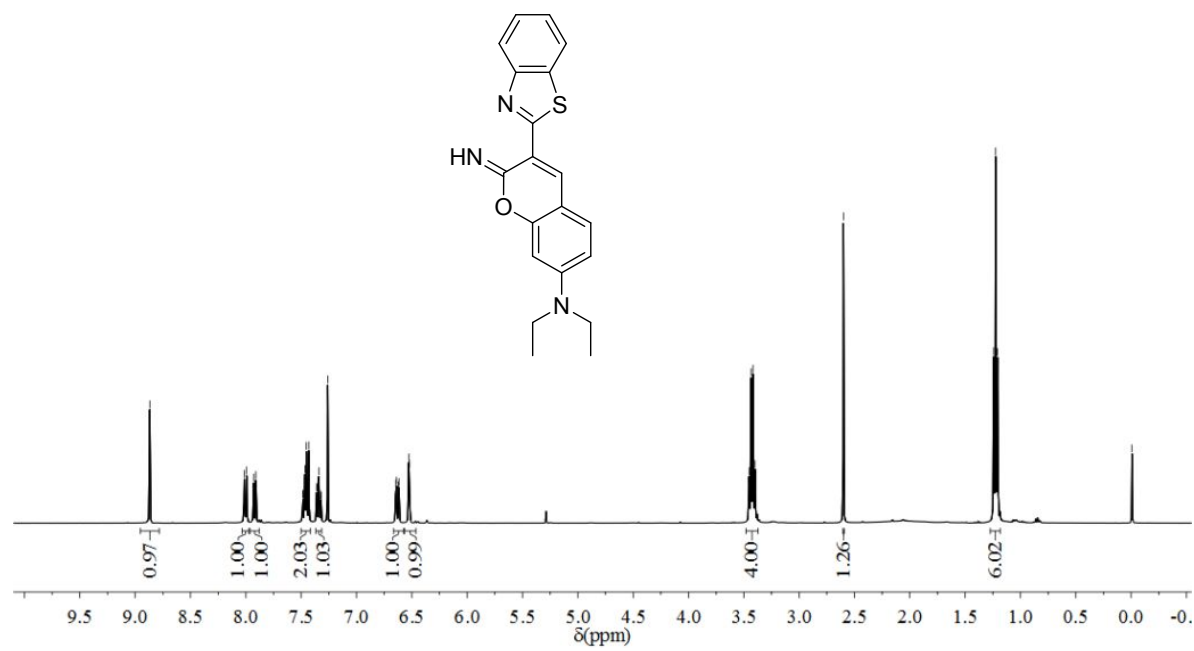

Figure S6. ${ }^{1} \mathrm{H}$ NMR spectrum of BTIC in $\mathrm{CDCl}_{3}$. 


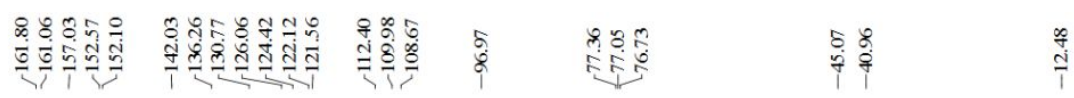

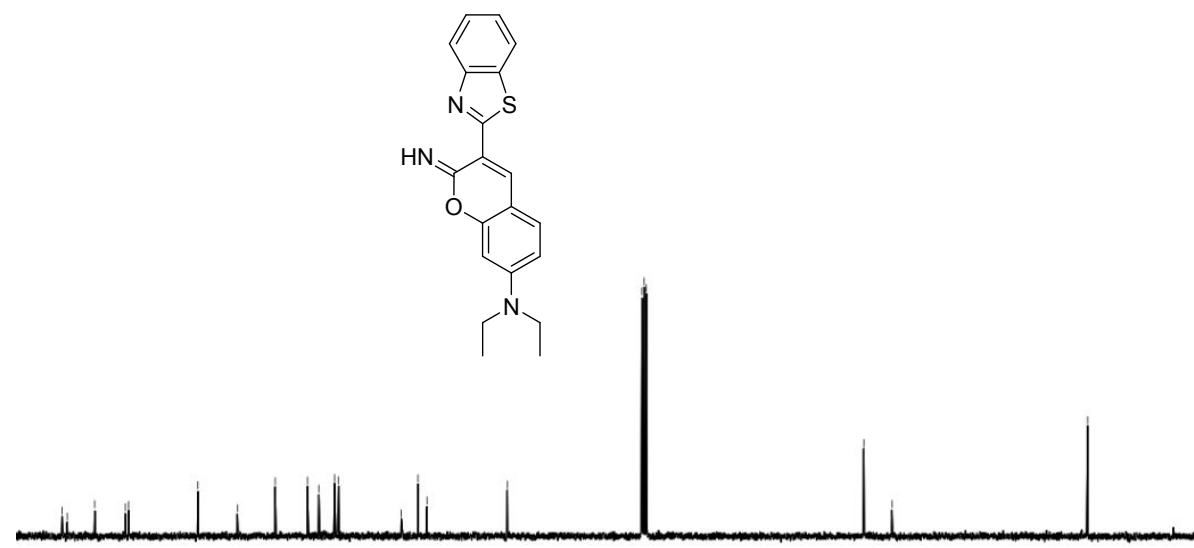

$\begin{array}{lllllllllllllllll}160 & 150 & 140 & 130 & 120 & 110 & 100 & 90 & \begin{array}{r}80 \\ \delta(\mathrm{pmm})\end{array} & 70 & 60 & 50 & 40 & 30 & 20 & 10 & 0\end{array}$

Figure S7. ${ }^{13} \mathrm{C}$ NMR spectrum of BTIC in $\mathrm{CDCl}_{3}$.

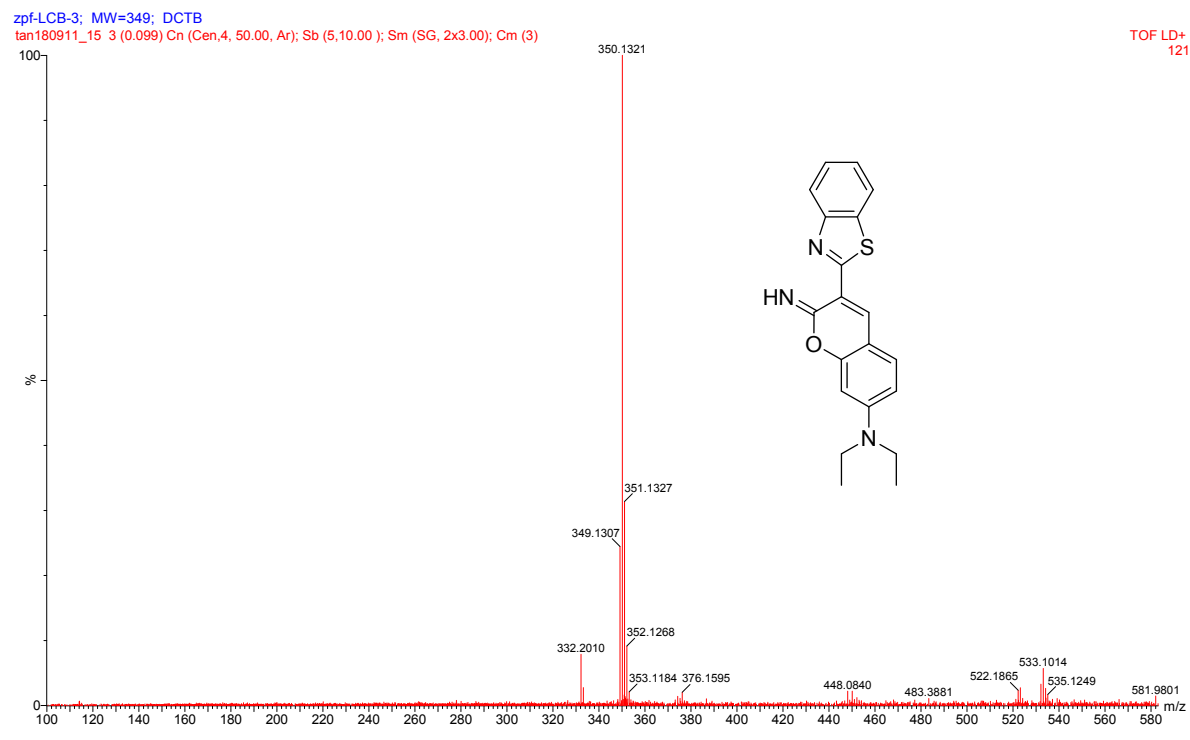

Figure S8. HRMS spectrum of BTIC. 

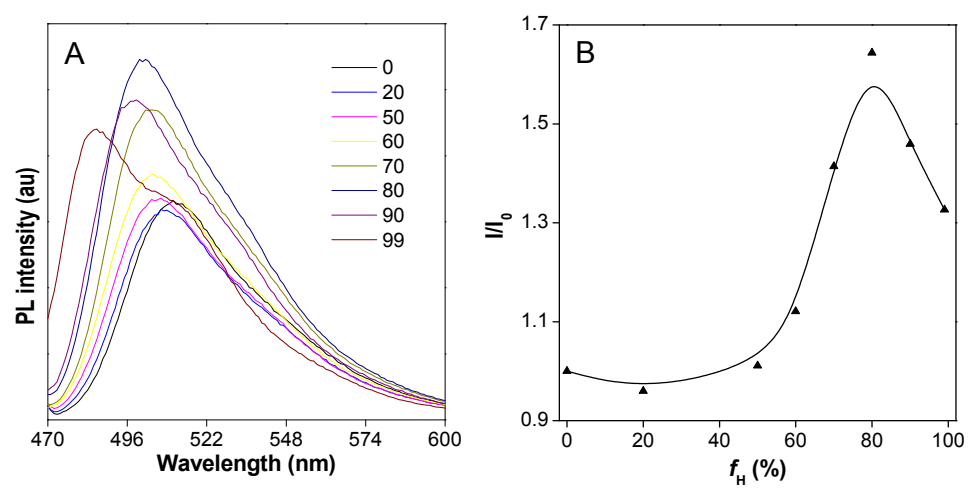

Figure S9. (A) PL spectra of BTIC in toluene/DMSO mixtures with different toluene fractions $\left(f_{\mathrm{H}}\right)$. (B) Plot of PL intensity of BTIC at maximum emission wavelength $v s . f_{\mathrm{H}}$ in the toluene/DMSO mixtures.
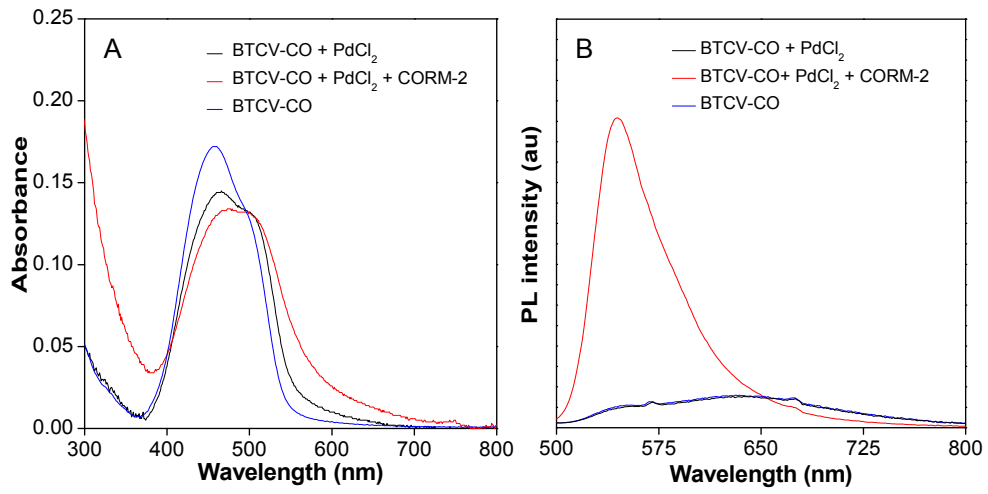

Figure S10. (A) UV/Vis spectra and (B) PL spectra of BTCV-CO $(5 \mu \mathrm{M}), \mathrm{BTCV}-\mathrm{CO}+\mathrm{PdCl}_{2}(5$ $\mu \mathrm{M})$ and BTCV-CO $+\mathrm{PdCl}_{2}+\mathrm{CORM}-2(50 \mu \mathrm{M})$ at $37^{\circ} \mathrm{C}$ for $20 \mathrm{~min}$ in $5 \% \mathrm{DMSO} / \mathrm{PBS}$ solution. Excitation wavelength $\left(\lambda_{e x}\right)=465 \mathrm{~nm}$.

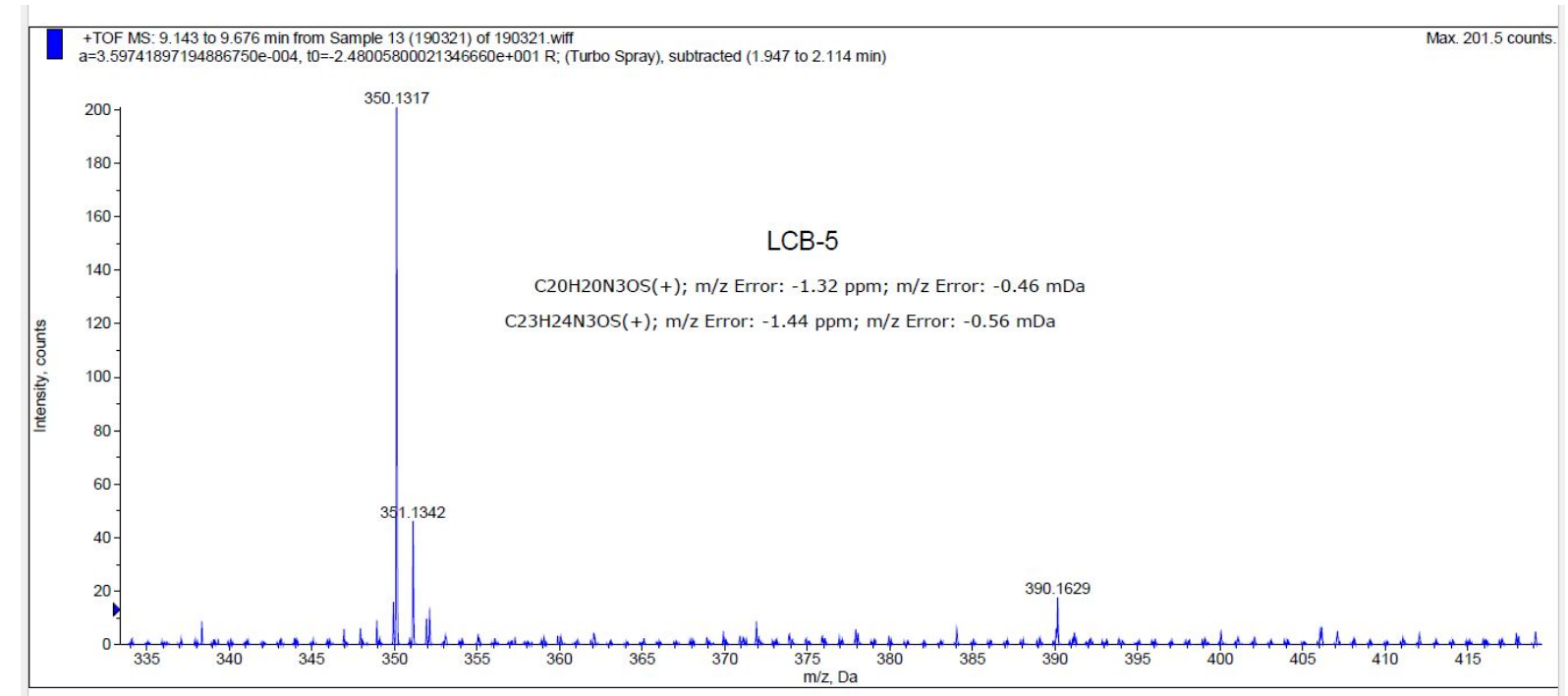

Figure S11. HRMS spectrum of BTCV-CO after incubation with $\mathrm{PdCl}_{2}$ and CORM-2 $(125 \mu \mathrm{M})$ at $37{ }^{\circ} \mathrm{C}$ for $20 \mathrm{~min}$. 


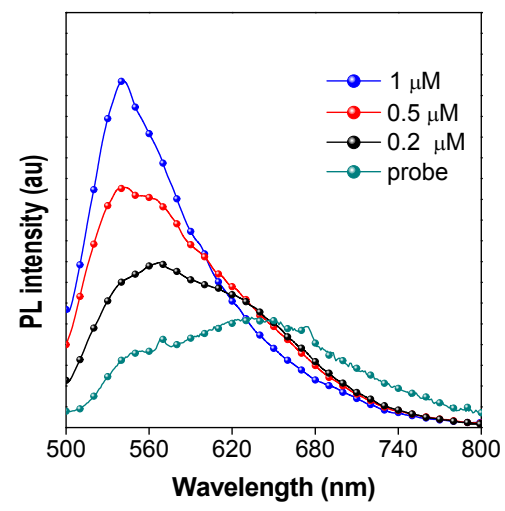

Figure S12. PL spectra of BTCV-CO (5 $\mu \mathrm{M}$ in PBS solution, $\mathrm{pH} 7.4$, containing 5\% DMSO) after incubation with CORM-2 $(125 \mu \mathrm{M})$ in presence of $\mathrm{PdCl}_{2}$ with different concentrations for 20 min.
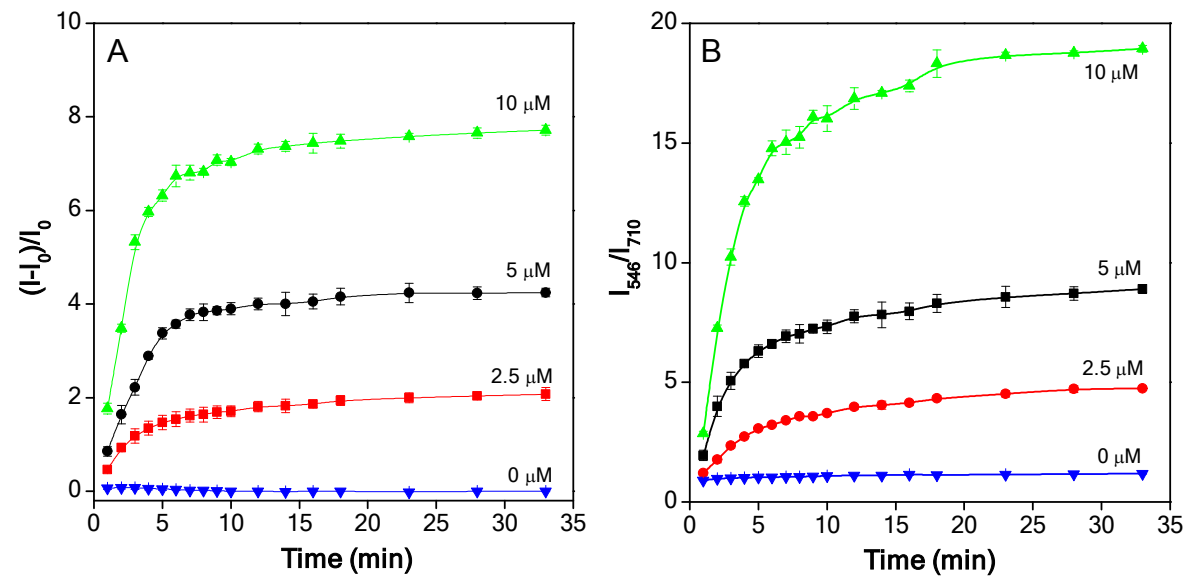

Figure S13. (A) The PL intensity ratios $\left(\left(I-I_{0}\right) / I_{0}\right)$ of BTCV-CO $(5 \mu \mathrm{M})+\mathrm{PdCl}_{2}(5 \mu \mathrm{M})$ at $546 \mathrm{~nm}$ in the presence of different concentrations of CORM-2 as a function of incubation time. (B) PL internsity ratios $\left(I_{546} / I_{710}\right)$ of BTCV-CO $(5 \mu \mathrm{M})+\operatorname{PdCl}_{2}(5 \mu \mathrm{M})$ in the presence of different concentrations of CORM-2 as a function of incubation time. $\lambda_{e x}=465 \mathrm{~nm}$.

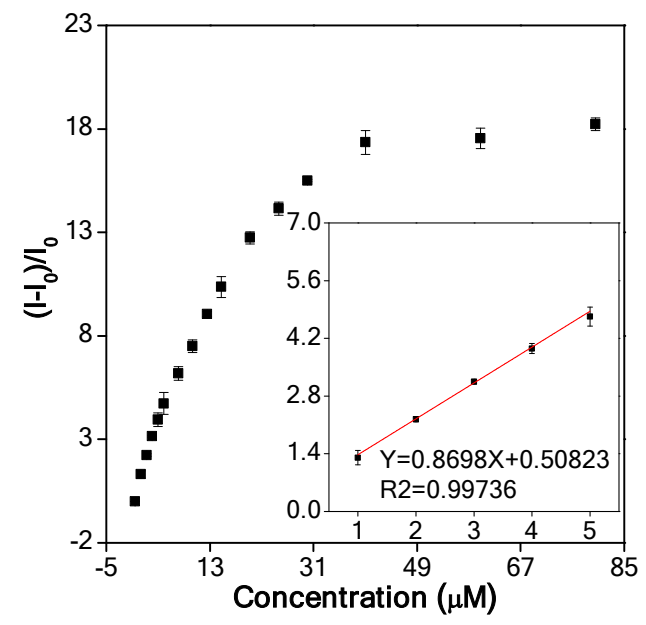

Figure S14.The PL intensity ratios $\left(\left(I-I_{0}\right) / I_{0}\right)$ of BTCV-CO $(5 \mu \mathrm{M})+\mathrm{PdCl}_{2}(5 \mu \mathrm{M})$ at $546 \mathrm{~nm}$ as a function of the concentration of CORM-2. Inset shows the linear relationship of the PL intensity ratios $\left(I_{546} / I_{710}\right)$ as a function of the concentration of CORM-2. $\lambda_{e x}=465 \mathrm{~nm}$. 

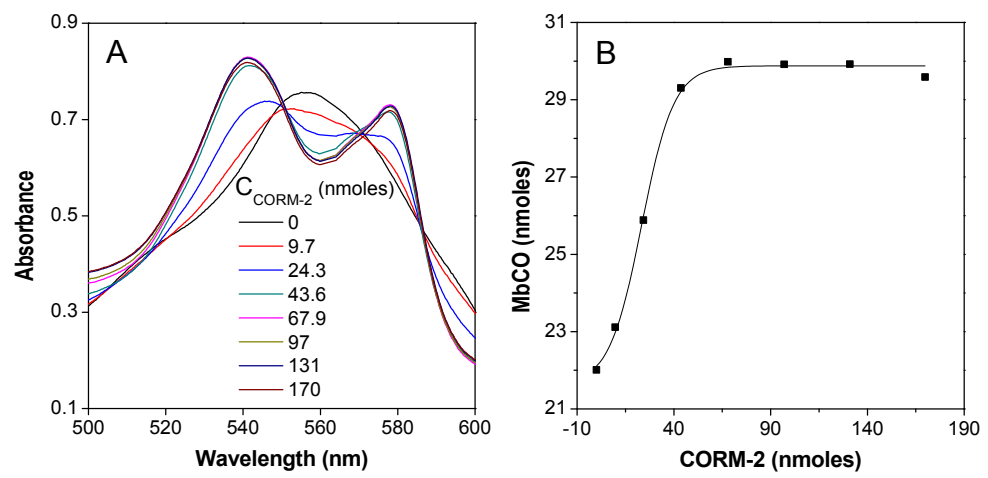

Figure S15. (A) Absorption spectrum of deoxy-Mb and $\mathrm{MbCO}$ before and after interaction of myoglobin with the different concentrations of CORM-2. (B) Determination of the amount of $\mathrm{MbCO}$ formed after interaction of deoxy-Mb with various concentrations of CORM-2.

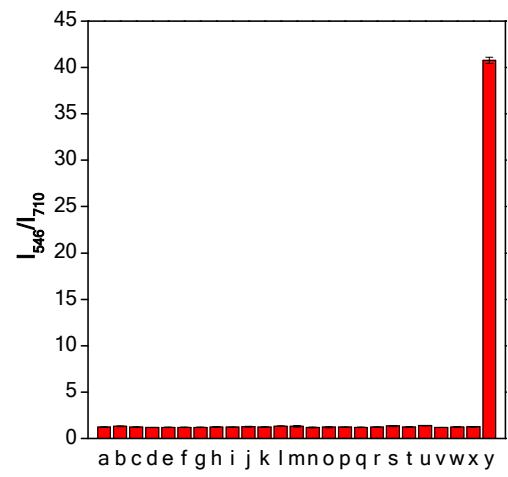

Figure S16.Variations of PL intensity ratios $\left(I_{546} / I_{710}\right)$ of BTCV-CO $(5 \mu \mathrm{M})+\mathrm{PdCl}_{2}(5 \mu \mathrm{M})$ after incubation with $100 \mu \mathrm{M}$ CORM-2 or other biologically-relevant species. a: $\mathrm{AcO}^{-}$; b: $\mathrm{ClO}^{-}$; c: Glu; d: Cys; e: GSH; f: $\mathrm{H}_{2} \mathrm{O}_{2}$; g: $\mathrm{H}_{2} \mathrm{~S}$; h: Hcy; i: $\mathrm{HNO}$; j: Ile; k: Leu; l: Trp; m: Br-; n: Cl; o: F-; p: $\mathrm{HCO}_{3}$; q: $\mathrm{NO}_{2}^{-}$; r: ·OH; s: ONOO-; t: $\mathrm{PdCl}_{2}$; u: Phe; v: ROO $;$ w: Ser; x: $\mathrm{SO}_{4}^{2-} ; \mathrm{y}: \mathrm{CORM}-2 . \lambda_{e x}=465$ nm.

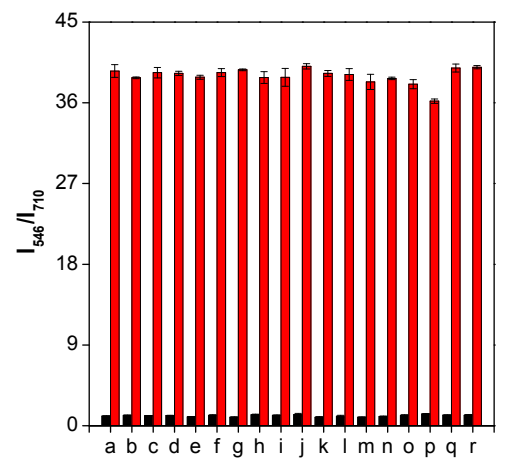

Figure S17. Variations of PL intensity ratios $\left(I_{546} / I_{710}\right)$ of BTCV-CO $+\mathrm{PdCl}_{2}$ (black bars) and BTCV-CO $+\mathrm{PdCl}_{2}+\mathrm{CORM}-2$ (red bars) after incubation with $100 \mu \mathrm{M}$ other biologically-relevant species. a: AcO-; b: Glu c:Cys; d:GSH; e:H2S; f: Hcy; g: Ile; h: Leu; i: Trp; j: Br-; k: Cl-; 1: F-; m: $\mathrm{HCO}_{3}{ }^{-} ; \mathrm{n}: \mathrm{NO}_{2}{ }^{-} ;$o: $\mathrm{PdCl}_{2}$; p: Phe; q: Ser; $\mathrm{r}: \mathrm{SO}_{4}{ }^{2-}$. Concentrations: BTCV-CO and $\mathrm{PdCl}_{2}: 5 \mu \mathrm{M}$; CORM-2: $100 \mu \mathrm{M} . \lambda_{e x}=465 \mathrm{~nm}$. 


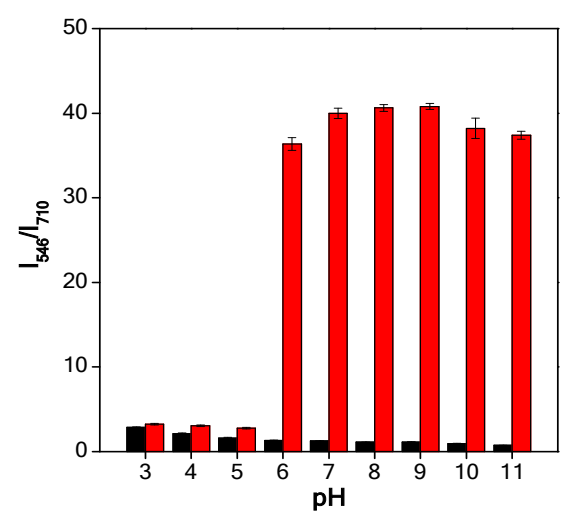

Figure S18.The PL intensity ratios $\left(I_{546} / I_{710}\right)$ of BTCV-CO $(5 \mu \mathrm{M}$, black bars) and BTCV-CO (5 $\mu \mathrm{M})+\mathrm{PdCl}_{2}(5 \mu \mathrm{M})+$ CORM-2 $(100 \mu \mathrm{M}$, red bars $)$ in different $\mathrm{pH}$ buffers. $\lambda_{e x}=465 \mathrm{~nm}$.

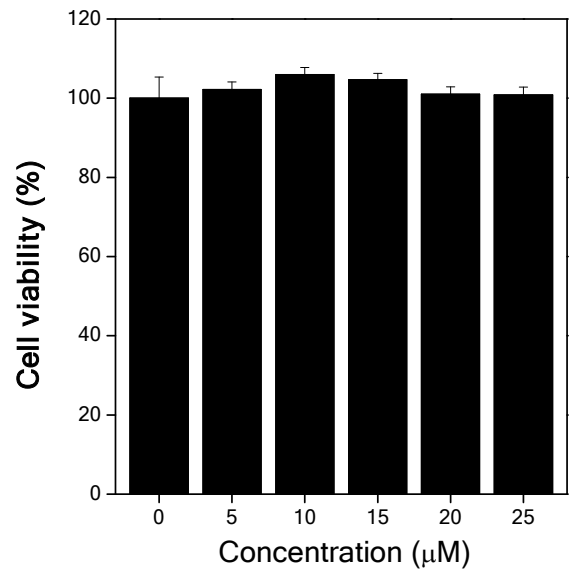

Figure S19. Cell viability of MCF-7 cells at varied concentrations of BTCV-CO by using standard MTT method.

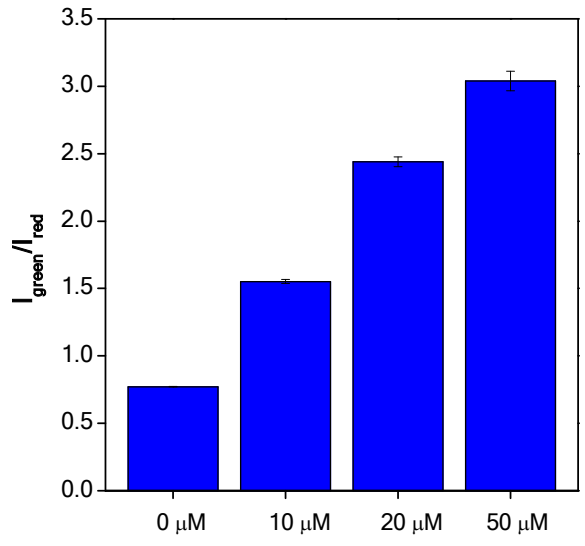

Figure S20. The PL intensity ratios $\left(I_{\text {green }} / I_{\text {red }}\right)$ of the green channel and red channel in Figure 3. 


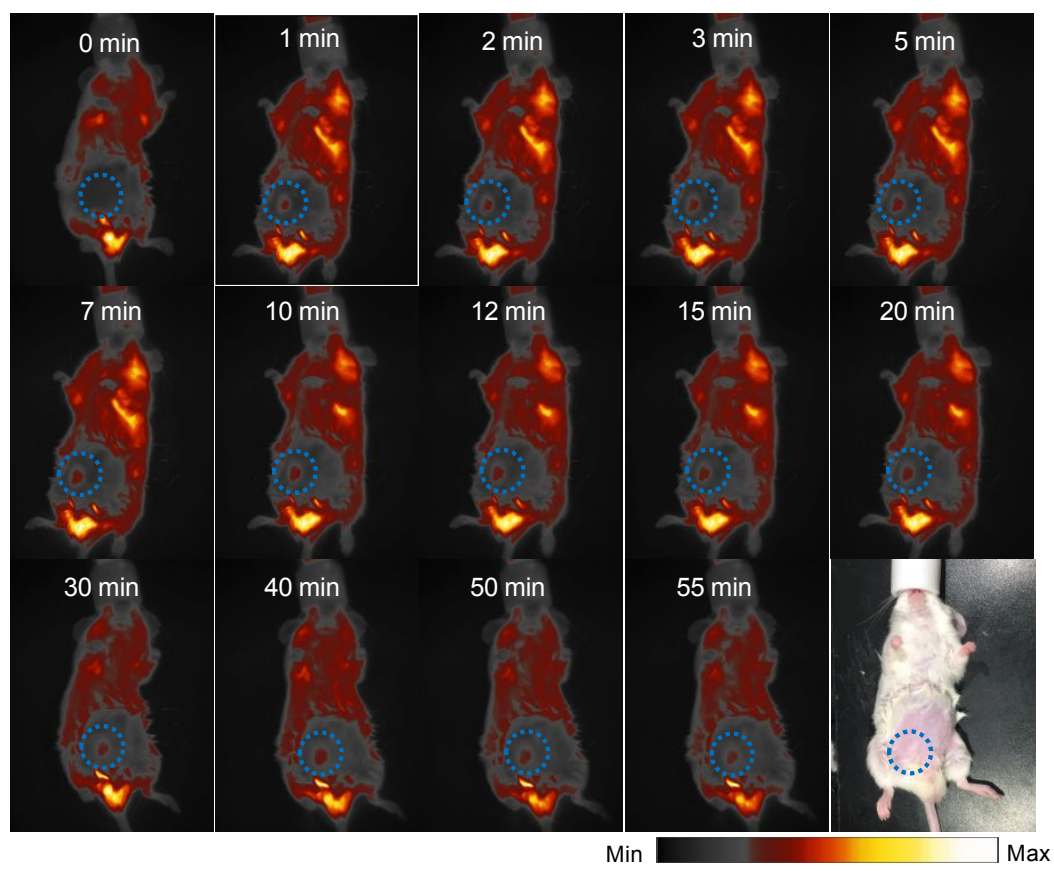

Figure S21. Time-dependent fluorescent images in live mice using probe BTCV-CO. BTCV-CO $(20 \mathrm{nM})$ and $\mathrm{PdCl}_{2}(20 \mathrm{nM})$ was injected in an intraperitoneal manner, followed by an injection of PBS $(30 \mu \mathrm{L})$. Fluorescent emissions were collected from 580 to $700 \mathrm{~nm}$. $\lambda_{\mathrm{ex}}=523 \mathrm{~nm}$.

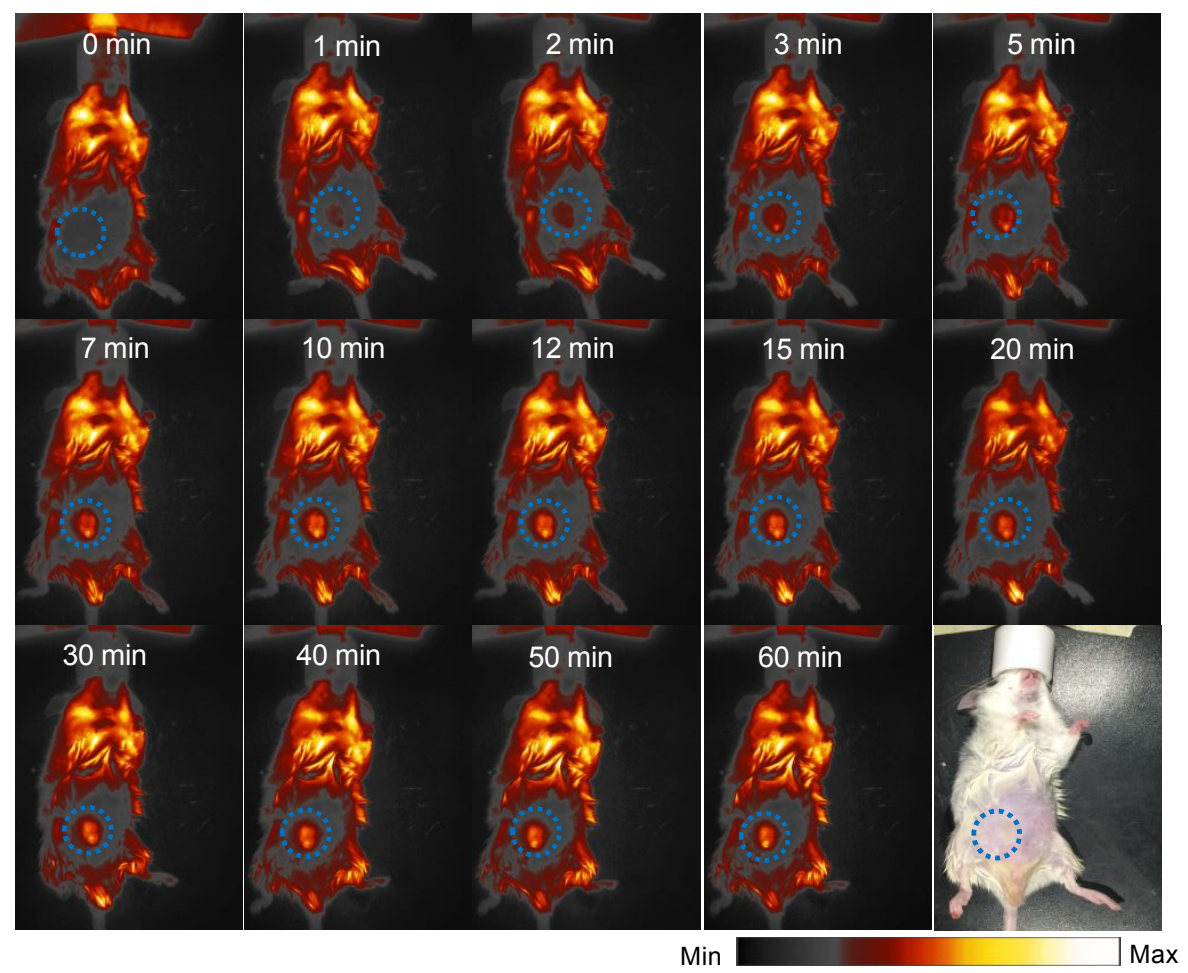

Figure S22. Time-dependent fluorescent images of $\mathrm{CO}$ in live mice using probe BTCV-CO. BTCV-CO $(20 \mathrm{nM})$ and $\mathrm{PdCl}_{2}(20 \mathrm{nM})$ was injected, followed by an injection of CORM-2 (150 $\mathrm{nM})$. Fluorescent emissions were collected from 580 to $700 \mathrm{~nm} . \lambda_{\mathrm{ex}}=523 \mathrm{~nm}$. 

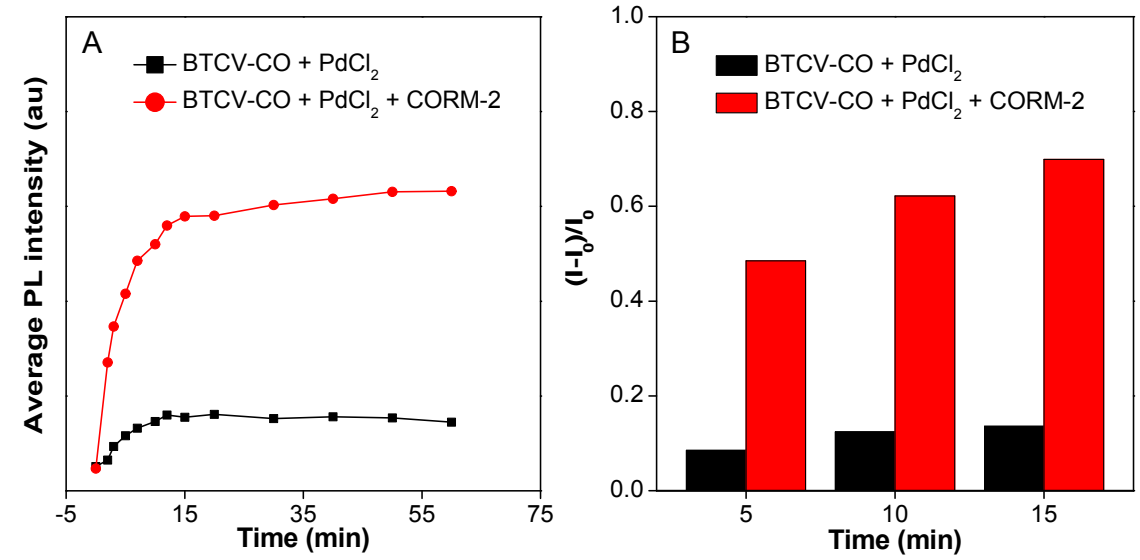

Figure S23. Time-dependent changes of average PL intensity $(\mathrm{A})$ and PL intensity ratio $\left(\left(I-I_{0}\right) / I_{0}\right)$ (B) in Figure S18 and S19. 
Table S1. Comparison of some fluorescent probes for CO detection.

\begin{tabular}{|c|c|c|c|c|c|}
\hline References & Response mode & $\begin{array}{l}\text { Response } \\
\text { time }\end{array}$ & $\begin{array}{c}\text { Detection } \\
\text { limit }\end{array}$ & $\lambda_{\mathrm{em}}$ & $\begin{array}{c}\text { Imaging } \\
\text { application }\end{array}$ \\
\hline Angew. Chem. Int. Ed. 51 (2012) 9652 & Turn-on (ACQ) & $10 \mathrm{~min}$ & $0.5 \mu \mathrm{M}$ & 528 & cell \\
\hline J. Am. Chem. Soc. 134 (2012) 15668 & Turn-on (ACQ) & $60 \mathrm{~min}$ & $1 \mu \mathrm{M}$ & 507 & cell \\
\hline Chem. Sci. 5 (2014) 3439 & Turn-on (ACQ) & $40 \mathrm{~min}$ & $0.653 \mu \mathrm{M}$ & 477 & cell/tissue \\
\hline Chem. Commun. 51 (2015) 4410 & Turn-on (ACQ) & $30 \mathrm{~min}$ & $8.49 \mathrm{nM}$ & 450 & cell \\
\hline Tetrahedron Lett. 26 (2016) 2927 & Turn-on (ACQ) & $30 \mathrm{~min}$ & $26.3 \mathrm{nM}$ & 549 & cell \\
\hline RSC Adv. 6 (2016) 65373 & Turn-on (ACQ) & $45 \mathrm{~min}$ & $0.127 \mu \mathrm{M}$ & 670 & cell \\
\hline Anal. Chem. 88 (2016) 11154 & Turn-on (ACQ) & $30 \mathrm{~min}$ & $0.72 \mu \mathrm{M}$ & 512 & cell \\
\hline Anal. Chem. 88 (2016) 10648 & Turn-on (ACQ) & $15 \mathrm{~min}$ & $37 \mathrm{nM}$ & 520 & cell \\
\hline Anal. Chem. 89 (2017) 3754 & Turn-on (ACQ) & $20 \mathrm{~min}$ & $\begin{array}{l}\text { 1: } 46 \mathrm{nM} \\
\text { 2: } 29 \mathrm{nM}\end{array}$ & $\begin{array}{l}\text { 1: } 516 \\
\text { 2: } 527\end{array}$ & cell \\
\hline Sens. Actuators B Chem. 240 (2017) 625 & Turn-on (ACQ) & $15 \mathrm{~min}$ & $25 \mathrm{nM}$ & 496 & cell \\
\hline J. Am. Chem. Soc. 139 (2017) 18484 & Turn-on (ACQ) & ND & ND & 450 & cell/ex vivo \\
\hline Angew. Chem. Int. Ed. 56 (2017) 13489 & Turn-on (ACQ) & $30 \mathrm{~min}$ & $0.5 \mathrm{nM}$ & 660 & $\begin{array}{c}\text { cell/zebrafish/tissue/ } \\
\text { organ } / \text { mice }\end{array}$ \\
\hline Anal. Chem. 90 (2018) 2933 & Turn-on (ACQ) & $45 \mathrm{~min}$ & $0.6 \mu \mathrm{M}$ & 525 & cell \\
\hline ACS sens. 3 (2018) 285 & Turn-on (ACQ) & $20 \mathrm{~min}$ & $0.06 \mu \mathrm{M}$ & 415 & cell \\
\hline Spectrochim. Acta A 202 (2018) 284 & Turn-on (ACQ) & $40 \mathrm{~min}$ & $57 \mathrm{nM}$ & 685 & cell \\
\hline Talanta $188(2018) 691$ & Turn-on (ACQ) & $18 \mathrm{~min}$ & $0.17 \mu \mathrm{M}$ & 736 & cell/tissue/mice \\
\hline Sens. Actuators B Chem. 255 (2018) 2314 & Turn-on (ACQ) & $3 \min$ & $3.2 \mathrm{nM}$ & 714 & cell $/$ mice \\
\hline New J. Chem. 42 (2018) 13497 & Turn-on (ACQ) & $45 \mathrm{~min}$ & $123 \mathrm{nM}$ & 520 & cell \\
\hline Anal. Chem. 90 (2018) 7117 & Turn-on (ACQ) & $40 \mathrm{~min}$ & $0.18 \mu \mathrm{M}$ & 550 & cell/zebrafish \\
\hline Anal. Methods, 11 (2019) 288 & Turn-on (ACQ) & $20 \mathrm{~min}$ & $38.9 \mathrm{nM}$ & 630 & cell \\
\hline Chem. Sci. 10 (2019) 320 & Turn-on (ACQ) & $30 \mathrm{~min}$ & $0.23 \mu \mathrm{M}$ & 650 & cell/tissue/mice \\
\hline Chem. Eur. J. 25 (2019) 2069 & Turn-on (ACQ) & ND & ND & 450 & cell \\
\hline Sens. Actuators B Chem. 291 (2019) 329 & Turn-on (ACQ) & $10 \mathrm{~min}$ & $6.1 \mathrm{nM}$ & 665 & cell/ zebrafish \\
\hline Sens. Actuators B Chem. 251 (2017) 389 & $\begin{array}{l}\text { Ratiometric } \\
\text { (ACQ) }\end{array}$ & $20 \mathrm{~min}$ & $58 \mathrm{nM}$ & $472 / 545$ & cell \\
\hline New J. Chem. 42 (2018) 14417 & $\begin{array}{l}\text { Ratiometric } \\
\text { (ACQ) }\end{array}$ & $25 \mathrm{~min}$ & $17.9 \mathrm{nM}$ & $545 / 455$ & cell \\
\hline Anal. Chem. 91 (2019) 2939 & $\begin{array}{c}\text { Ratiometric } \\
\text { (ACQ) }\end{array}$ & $60 \mathrm{~min}$ & $0.44 \mu \mathrm{M}$ & $540 / 610$ & cell/tissue/D. magna \\
\hline This work & $\begin{array}{c}\text { Ratiometric } \\
\text { (AIE) }\end{array}$ & $20 \mathrm{~min}$ & $30.8 \mathrm{nM}$ & $564 / 710$ & cell/mice \\
\hline
\end{tabular}




\section{References:}

(S1) Beckman, J. S.; Chen, J.; Ischiropoulos, H.; Crow, J. P. Method. Enzymol. 1994, 233, 229-240. 